Nordiska

ministerrådet

\title{
NORDISKA ARBETSPAPPER
}

\section{Könsfördelning i Nordiska rådets \\ kulturpriser}




\section{Könsfördelning i Nordiska rådets kulturpriser}

Följande undersökning är en kvantitativ översikt av fördelning mellan kvinnor och män i de fyra nordiska kulturpriserna. Uppgifterna är insamlade i januari 2017 på www.norden.org. På grund av prisernas olika historia och struktur har olika tekniker använts för att bedöma könsbalans. Respektive metod anges i fotnot.

Denna undersökning och analys utreder endast könsfördelning av nominerade och pristagare av Nordiska rådets kulturpriser, det vill säga det kvantitativa utfallet av nominering- och röstningsprocesser, och därmed jämställdhetsperspektivet i sin enklaste form. Inga ytterligare intersektionella perspektiv utöver kön undersöks heller.

\section{Litteraturpriset}

Sedan 1962 delas litteraturpriset ut för ett skönlitterärt verk av en nulevande författare på ett av de nordiska språken. Sekretariat for Nordisk Råds litteraturpris är Nordens hus i Reykjavik.

Mellan 1962 och 2016 har 56 författare vunnit Nordiska rådets litteraturpris (två vinnare år 1965). Utav de är 43 män (77\%) och 13 kvinnor (23\%). Under 60- och 70-talet var alla prisvinnarna män fram till 1980 när Sara Lidman var den första kvinnan att tilldelas litteraturpriset. Sedan 90-talets början har könsfördelningen jämnats ut och de senaste tio åren, 2007 - 2016, har fem kvinnor och fem män blivit tilldelade litteraturpriset. Under denna period har 130 författare totalt nominerats. Även bland de nominerade har hälften varit kvinnor (64 personer) och hälften män (66 personer).

Utveckling av könsfördelningen för Nordiska rådets litteraturpristagare från 1962 till 2016 (samt en jämförande stapel för könsfördelning av nominerade författare 2007-2016)

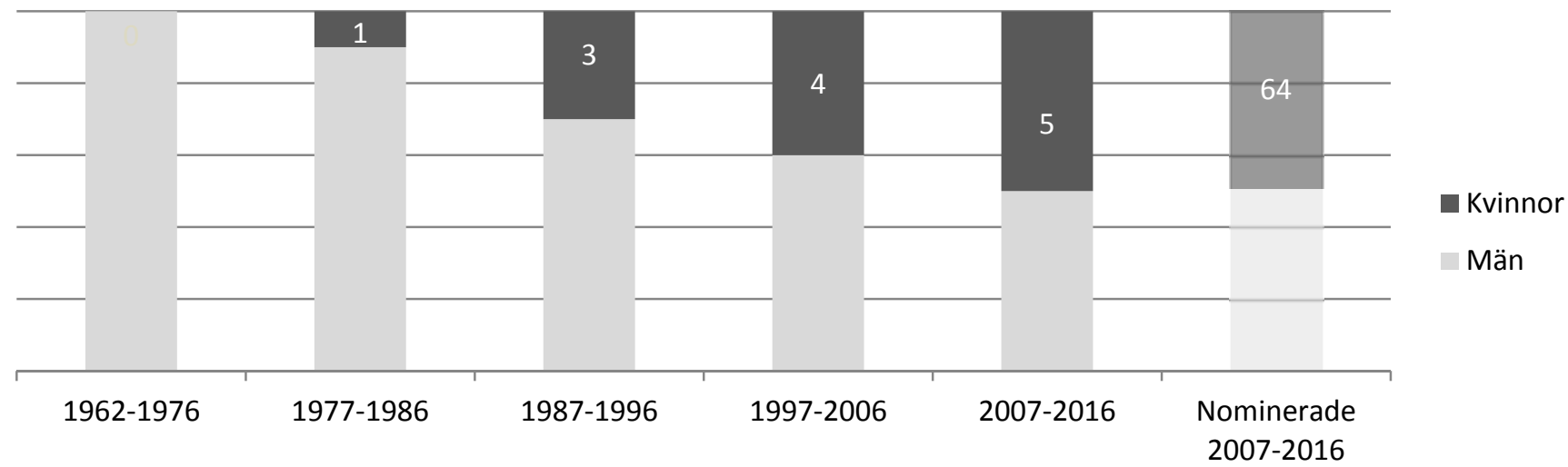

Kvinnor och män som har tagit emot Nordiska rådets litteraturpris mellan 1952 och 2016. Samt nominerade till Nordiska rådets litteraturpris mellan 2007 och 2016.

Källa: http://www.norden.org/sv/nordiska-raadet/nordiska-raadets-priser/nordisk-raads-litteraturpris/vinnare.

Hämtat den 3 januari 2017 


\section{Filmpriset}

Sedan 2005 (och en gång 2002) delas filmpriset ut till en nordiskt producerad film med speltid på minst 72 minuter. Priset delas av regissör, manusförfattare och producent. Nordiska rådets filmpris administreras av Nordisk Film \& TV Fond.

Under tioårsperioden 2007-2016 har 80\% av de nominerade, och $87 \%$ av pristagarna, varit män ${ }^{1}$. Cirka hälften av de nominerade filmerna, $48 \%$ (och $60 \%$ av de som vunnit) har uteslutande män på alla tre positioner. En av de nominerade filmerna de senaste tio åren (och ingen av de som har vunnit) har haft kvinnor som regissör, manusförfattare och producent. De kvinnor som har nominerats är övervägande producenter (två tredjedelar av de kvinnliga nomineringarna).

\section{Antal/andel nominerade kvinnor och män till filmpriset 2007-2016}

\begin{tabular}{|l|r|r|r|}
\hline & Kvinnor & Män & Total \\
\hline \multirow{2}{*}{ Nominerade } & 32 & 130 & 162 \\
\cline { 2 - 4 } & $20 \%$ & $80 \%$ & $100 \%$ \\
\hline \multirow{2}{*}{ Prisvinnare } & 4 & 26 & 30 \\
\cline { 2 - 4 } & $13 \%$ & $87 \%$ & $100 \%$ \\
\hline
\end{tabular}

Sedan 2007 har en kvinnlig regissör mottagit filmpriset (år 2011) och ingen kvinnlig manusförfattare. Könsproportionerna tycks vara mer eller mindre oföränderliga sedan tio år tillbaka och pekar inte på någon utveckling.

\section{Könsfördelning bland de nominerade till Nordiska rådets filmpris mellan 2007 och 2016 (vänster) och pris- tagarna för samma period (höger)}
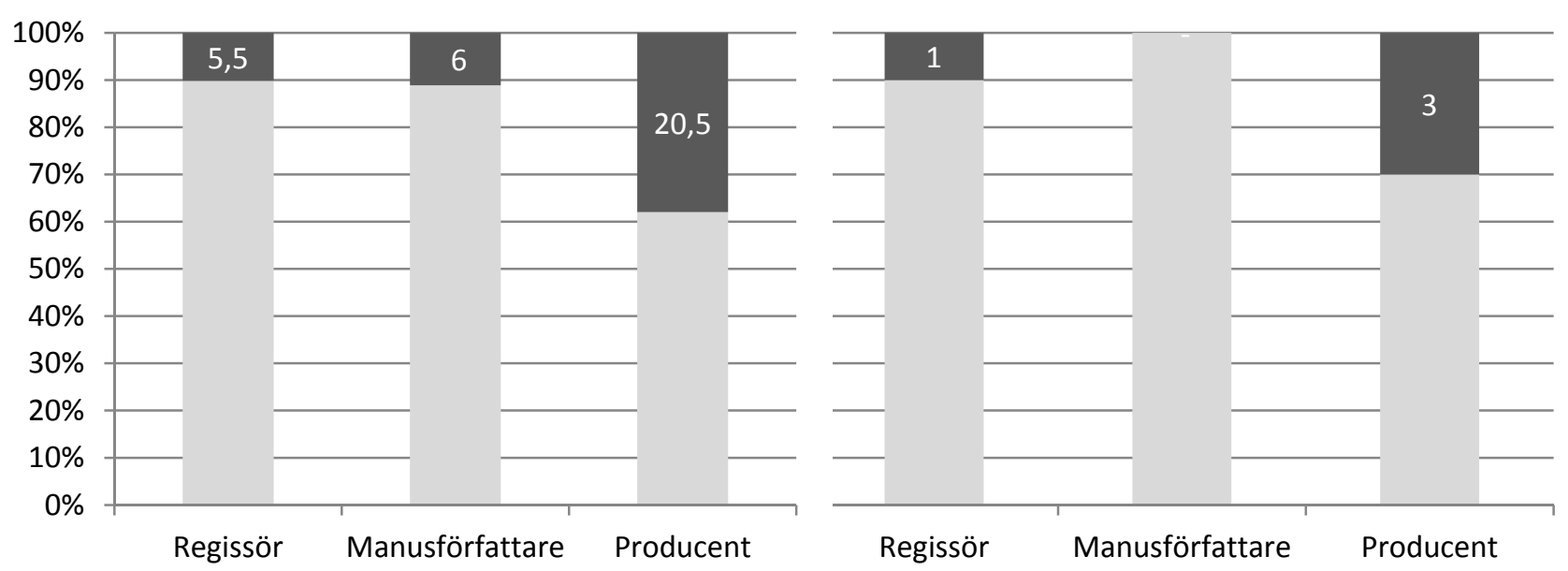

Kvinna

Man

Nominerade och pristagande regissörer, manusförfattare och producenter av Nordiska rådets filmpris mellan 2007 och 2016.

Varje film har tre nomineringsposter och i de fall där det är mer än en person per regissör, manusförfattare eller producent delas

IVIUSIK-

priset de upp så att det totalt blir ett.

Källa:http://www.norden.org/da/nordisk-raad/nordisk-raads-priser/nordisk-raads-filmpris-1/tidligere-prisvindere-og-nominerede

\footnotetext{
${ }^{1}$ Metod: Filmpriset delas mellan manusförfattare, regissör och producent. I de flesta fall är detta tre olika personer men ibland endast en eller två och ofta fler än tre personer (det vill säga två eller fler manusförfattare, regissörer eller producenter). Om till exempel fler än en man är manusförfattare, räknas detta som en person. Om det är en man och en kvinna, räknas det som 0,5 var. Det räknas som att tre personer vinner varje år, och den totala summan är därmed det totala antalet filmer som ingår i det urval som undersöks multiplicerat med tre. Om samma person är regissör, manusförfattare och producent, räknas denne tre gånger.
} 
las Nordiska rådets musikpris ut (varje år sedan 1990). Vartannat år ges priset till ett verk av en nu levande kompositör och vartannat år går priset till en större eller mindre ensemble eller en enskild musiker. Sekretariat for Nordisk Råds musikpris är Nordens Hus på Färöarna.

Utan att räkna med de största musikgrupperna (fler än tio personer) har $73 \%$ av de nominerade till musikpriset mellan 2007 och 2016 varit män, och 83\% av vinnarna ${ }^{2}$. De fem år som kompositörer har nominerats har 79\% varit män.

De senaste tio åren har åtta enskilda personer vunnit varav en kvinna och sju män. År 2008 vann en duo med en kvinna och en man och år 2007 vann en kör som överstiger storleken för denna statistik och därmed utelämnats.

\section{Andel nominerande och pristagande akter mellan 2007 och 2016 fördelat på kvinnor, män eller fler än tio personer (t.ex. körer)}

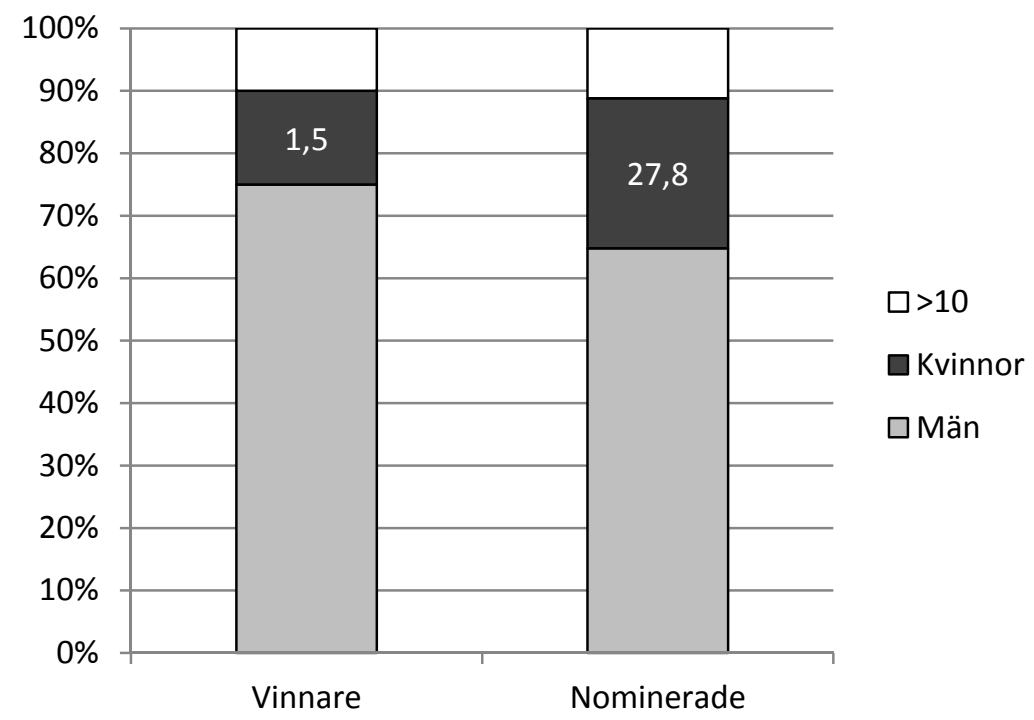

Barn- och ungdomslitteraturpriset

Barn- och ungdomslitteraturpriset instiftades år 2013 och uträkningen baseras därför på endast fyra års verksamhet. Sekretariat för Nordiska rådets barn- och ungdomslitteraturpris är Nordens hus i Reykjavik.

Bland de totalt 54 nominerade verken har 37,7 (70\%) varit kvinnliga och 16,3 (30\%) manliga3. Bland kvinnorna är cirka en tredjedel av de nominerade illustratörer medan $13 \%$ av de nominerade männen är illustratörer.

Under de fyra åren har sammanlagt sex personer mottagit priset (de vinnande böckerna år 2013 och år 2015 skapades av två personer). Fem är män och en är kvinna. Proportionerna för nominerade män och kvinnor är relativt oförändrad över de fyra år som priset har funnits.

\footnotetext{
${ }^{2}$ Metod: Varje verk räknas som en person. Det vill säga att om det är flera medlemmar divideras de så att kvoten blir ett. I de fall där det nominerade verket, ensemblen, kören, orkesterns eller musikgruppen överstigar ett medlemsantal på tio personer har könsbalansen inte räknats ut och de utgör en kategori för sig (=13 stycken av de nominerade akterna och en av de vinnande).

3 Varje nominering räknas som en, det vill säga att om det är flera nominerade har de dividerats på 1 .
} 
Antal nominerade och pristagande kvinnor och män mellan år 2013 och $2016^{4}$

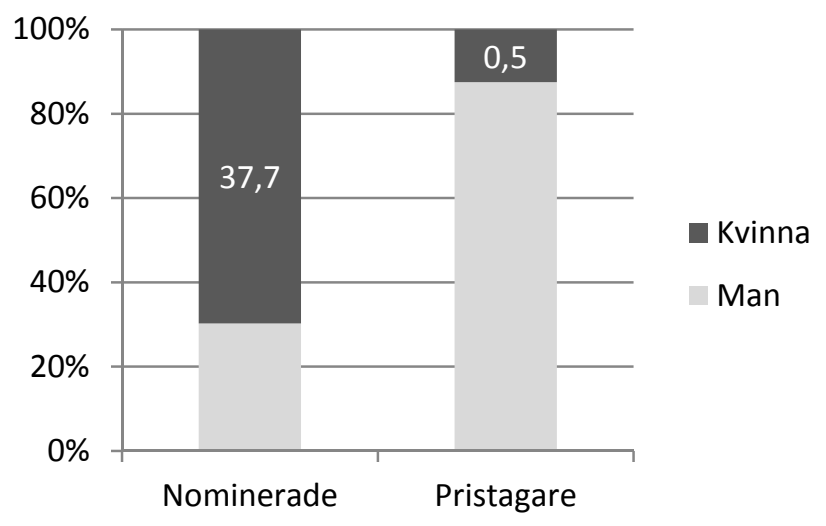

\begin{abstract}
Nominerade och pristagare av Nordiska rådets barn- och ungdomslitteraturpris mellan 2013 och 2016, fördelade på principen om att en person per nominering.

Källa: http://www.norden.org/da/nordisk-raad/nordisk-raadspriser/nordisk-raads-boerne-og-ungdomslitteraturpris/tidligereprisvindere-og-nominerede
\end{abstract}

\title{
Varierande könsfördelning i de fyra priserna
}

Litteraturprisets nominerade och pristagare är de senaste tio åren jämnt fördelade mellan könen och statistsikt sätt jämställda vad gäller kvinnor och män.

Filmpriset och musikpriset är mer ojämnt könsbalanserade. Det är en större statistisk utmaning att representera könsfördelningen på ett allmängiltigt sätt eftersom att antalet nominerade per verk varierar. Men för båda priserna finns tydliga och oförändrade tendenser till att fler män nomineras. Fördelningen bland nominerade följer även till pristagare.

Barn-och ungdomslitteraturpriset har endast funnits fyra år och kan inte visa på långsiktiga resultat men tendensen är att fler kvinnor nomineras till priset men att när pristagaren/na utses har de senaste fyra åren fler män vunnit. Könsbalans bland nominerade och bland pristagare korrelerar i alla pris utom i barn-ungdomslitteraturpriset.

\footnotetext{
${ }^{4}$ Metod: Under de fyra år som barn- och ungdomslitteraturpriset har delats ut, har 54 böcker nominerats (13 eller 14 böcker per år, beroende på om Åland har nominerad ett verk eller ej). Det varierar huruvida en eller flera författare och illustratörer är nominerade för de respektive böckerna. Varje nominerat verk ger i denna uträkning upphov till ett "poäng", det vill säga att om en man och en kvinna skapat en bok tillsammans räknas de som 0,5 vardera.
} 